\title{
RETRACTION
}

\section{The effect of exercise on mobilization of hematopoietic progenitor cells involved in the repair of sciatic nerve crush injury}

TO THE EDITOR: We regretfully retract the following paper in response to accusations that it contains materials that constitute plagiarism, duplicate publication, and copyright infringement:

Cheng FC, Sheu ML, Su HL, Chen YJ, Chen CJ, Chiu WT, Sheehan J, Pan HC: The effect of exercise on mobilization of hematopoietic progenitor cells involved in the repair of sciatic nerve crush injury. J Neurosurg 118:594-605, 2013.

\section{Reasons for Retraction}

1. There is some text overlap between the 2013 Journal of Neurosurgery (J Neurosurg) paper and the following article by the same research group, which appeared in Biochemical and Biophysical Research Communications:

Pan HC, Wu HT, Cheng FC, Chen CH, Sheu ML, Chen CJ: Potentiation of angiogenesis and regeneration by G-CSF after sciatic nerve crush injury. Biochem Biophys Res Commun 382:177-182, 2009.

We agree that overlap is present in the Introduction and Methods sections, and we did not provide sufficient attribution to the earlier paper.

2. Some figure panels in the $J$ Neurosurg paper have similar content to those in an earlier article published in the $J$ Neurosurg, which shares some authors with the paper currently being retracted:

Cheng FC, Tai MH, Sheu ML, Chen CJ, Yang DY, Su HL, Ho SP, Lai SZ, Pan HC:
Enhancement of regeneration with glia cell linederived neurotrophic factor-transduced human amniotic fluid mesenchymal stem cells after sciatic nerve crush injury. J Neurosurg 112:868-879, 2010.

There is overlap in content between a few panels shown in Figs. 3 and 4 in the 2013 J Neurosurg paper and a few panels displayed in Figs. 3 and 4, respectively, in the 2010 J Neurosurg paper. In addition, we did not provide attribution to the earlier paper.

With respect to the text, before we submitted our manuscript, we used the anti-plagiarism program iThenticate to ensure that our manuscript would have less than $30 \%$ overlap with previous papers. We believed that this was sufficient, but actions taken by complainants and the Journal of Neurosurgery Publishing Group show that is not the case.

As to the complaint that there was overlap in our figures, it has been several years since we began to prepare the manuscript. Since that time, we did find similarities in one figure between our two J Neurosurg papers. We were in the process of correcting this error when the complaint was made. Unfortunately, our original data are no longer available, and we are unable to refer to them for additional clarification.

We apologize to the Editor and Readership of the Journal of Neurosurgery, and we hereby retract our $2013 \mathrm{~J}$ Neurosurg paper (J Neurosurg 118:594-605, 2013). As corresponding author, I retract this article on behalf of all authors.

Hung-Chuan Pan, MD, PhD

School of Medicine, National Yang-Ming University, Taipei, Taiwan Taichung Veterans General Hospital, Taichung, Taiwan

\section{INCLUDE WHEN CITING}

Published online October 2, 2015; DOI: 10.3171/2015.7.JNS111580r.

CAANS, 2015 